\title{
Analisis Persepsi Anggota Koperasi Terhadap Perbaikan Layanan Dari Dampak Penggunaan Sistem Simpan Pinjam Koperasi Divif 1 Kostrad Depok
}

\author{
Elmor Benedict Wagiu dan Rianto Doharma Sihotang \\ Fakultas Teknologi Informasi, Universitas Advent Indonesia
}

\begin{abstract}
Abstrak
Penelitian proses bisnis yang terjadi di dalam Koperasi Divif 1 Kostrad bertujuan untuk mengetahui mutu pelayanan yang diberikan kepada anggota. Permasalahan yang muncul saat ini adalah bagaimana dampak pengguna layanan terhadap sistem yang terjadi pada Koperasi Simpan Pinjam dan apakah akan dipengaruhi oleh persepsi anggota dengan kualitas sistem yang digunakan saat ini. Pengambilan sampel sebanyak 89 responden yang dibagi tiga divisi menggunakan teknik purposive sampling dengan perhitungan rumus slovin dan pengumpulan data melalui kuesioner. Adapun tujuan penelitian yaitu : (1) Mengetahui bagaimana pengaruh pengguna dalam sistem pelayanan di Koperasi Simpan Pinjam, akan adanya penambahan fungsi dalam sistem atau pembaharuan alat pendukung sistem. (2) Mengetahui apakah persepsi kepuasan dan persepsi kelayakan berpengaruh terhadap penerimaan anggota Tentara Nasional Indonesia (TNI) Kostrad dari dampak penggunaan Sistem Koperasi Simpan Pinjam. Penulis menghitung hasil penelitian menggunakan rumus metode penelitian kuantitatif Sugiyono. Hasil penelitian dari kuesioner menunjukkan bahwa persepsi kepuasan dan persepsi kelayakan sangat mempengaruhi terhadap dampak penggunaan Sistem Koperasi Simpan Pinjam.

Kata-kata kunci: purposive sampling, penelitian kuantitatif, SPSS, koperasi simpan pinjam
\end{abstract}

\section{Perception Analysis of Cooperative Members Against Service Improvement from Impact of Use Cooperative Savings and Loans System Divif 1 Kostrad Depok}

\begin{abstract}
Business process research that occurs in the Divif 1 Kostrad Cooperative aims to determine the quality of services provided to the members. The problem that arises is how the impact of service users on the system occurs in the Savings and Loan Cooperative and whether it will be influenced by members perceptions of the quality of the system used right now. 89 sampled respondents are divided into three divisions using purposive sampling technique with calculation of Slovin formula and data collection through questionnaires. The research objectives are: (1) Knowing how users influence the service system in the Savings and Loan Cooperative on additional functions in the system or renewal of system support tools. (2) Knowing whether perceptions of satisfaction and feasibility perceptions influence the acceptance of members of the Tentara Nasional Indonesia (TNI) Kostrad from the impact of using the Savings and Loan Cooperative System. The author calculates the results of the research using Sugiyono's quantitative research method formula. The results of the research from the questionnaire indicate that perceptions of satisfaction and perceptions of feasibility influence the impact of using the Savings and Loan Cooperative System.
\end{abstract}

Keywords: purposive sampling, quantitative research, SPSS, savings and loan cooperatives

\section{Pendahuluan}

Perkembangan teknologi pada jaman ini membuat semua hal dapat dipermudah oleh sistem yang bekerja lebih efisien membantu manusia. Pemanfaatan sistem informasi menjadi suatu keharusan yang tidak dapat dihindari oleh setiap perusahaan yang ingin menempatkan dirinya pada posisi paling depan dalam suatu industri. Oleh karena itu, kemampuan sistem informasi memegang peranan yang sangat penting untuk menunjang suksesnya sebuah perusahaan.

Penelitian ini dilakukan di Koperasi Divif 1 Kostrad. Koperasi ini dibuat khusus untuk anggota Tentara Nasional Indonesia (TNI) sehingga semua orang yang terlibat didalamnya merupakan anggota TNI. Mutu pelayanan koperasi simpan pinjam adalah faktor yang dapat meningkatkan kepuasan anggota koperasi. Kualitas pelayanan merupakan totalitas bentuk dari karakteristik barang atau jasa yang 
menunjukan kemampuannya untuk memuaskan kebutuhan- kebutuhan user. Dalam meningkatkan kualitas layanan, pengelolaan keluhan dari anggota dibutuhkan wawancara secara tertulis maupun penyebaran kuesioner untuk mengukur kepuasan anggota. Keluhan anggota dapat memberikan dampak buruk atau tidak menguntungkan apabila hal itu tidak diselesaikan dengan baik.

Permasalahan yang terjadi saat ini dalam koperasi simpan pinjam Divif 1 Kostrad adalah terjadinya antrian user dalam bertransaksi dikarenakan tenaga karyawan yang terbatas dan sistem yang digunakan belum ter-update dengan baik. Sehingga mengakibatkan error pada saat penginputan data di sistem yang mengakibatkan terhambatnya pelayanan terhadap anggota.

Oleh karena itu peneliti ingin menganalisis bagaimana penerapan sistem informasi yang sedang berjalan saat ini di Koperasi Divif 1 Kostrad Depok. Sehingga berharap dapat mengetahui dan mengeksploitasi terhadap perbaikan layanan yang terjadi terkait ketersediaan dalam melakukan transaksi peminjaman maupun tabungan secara rutin. Untuk mengetahui dan mengukur seberapa besar persepsi kepuasan dan kelayakan sistem informasi, seberapa sederhana dan mudah sistem informasi itu dipraktekkan dan seberapa besar peningkatan kinerja dapat dicapai berkat adanya sistem informasi itu.

\section{Hipotesis Penelitian}

Dalam menghasilkan suatu hasil keputusan penerimaan pengguna atau keluhan dilihat berdasarkan pengumpulan sampel data yang dilakukan. Peneliti melakukan uji hipotesis sesuai dengan permasalahan yang mempengaruhi dalam pelayanan dan kepuasan pengguna di Koperasi Divif-1 Kostrad. Uji hipotesis yang digunakan dalam penelitian ini adalah uji t atau distribusi t, melalui langkahlangkah berikut :

\section{Hipotesis 1}

H0 : Persepsi Kepuasan tidak berpengaruh signifikan terhadap Perbaikan Layanan dari Dampak Penggunaan Sistem

Ha: Persepsi Kepuasan berpengaruh signifikan terhadap Perbaikan Layanan dari Dampak Penggunaan Sistem

\section{Hipotesis 2}

H0: Persepsi Kelayakan Sistem tidak berpengaruh signifikan terhadap Perbaikan Layanan dari Dampak Penggunaan Sistem

Ha: Persepsi Kelayakan Sistem berpengaruh signifikan terhadap Perbaikan Layanan dari Dampak Penggunaan Sistem

\section{Hipotesis 3}

H0: Persepsi Kepuasan dan Kelayakan Sistem tidak berpengaruh signifikan terhadap Perbaikan Layanan dari Dampak Penggunaan Sistem

Ha: Persepsi Kepuasan dan Kelayakan Sistem berpengaruh signifikan terhadap Perbaikan Layanan dari Dampak Penggunaan Sistem

\section{Landasan Teori}

\section{Persepsi Kepuasan}

Menurut Kotler dan Keller (2009:14), Pengertian kata kepuasan atau satisfaction berasal dari bahasa latin "satis yang berarti cukup baik, memadai dan facio yang berarti melakukan atau membuat. Menandakan bahwa kepuasan adalah perasaan senang atau kecewa seseorang yang timbul karena membandingkan kinerja yang dipersepsikan produk (atau hasil) terhadap ekspektasi mereka. Untuk mengetahui masalah kepuasan konsumen terlebih dahulu harus didapati pengerti arti kepuasan itu sendiri. Kepuasan merupakan suatu respon emosi seseorang terhadap suatu hal yang tengah dihadapinya. Emosi berarti menunjukan perasaan suka atau tidak suka terhadap suatu hal.

Dapat disimpulkan bahwa persepsi kepuasan merupakan bentuk ekspresi seseorang terhadap sesuatu hal yang dilihatnya. Dapat terlihat kecewa maupun senang tergantung dari kondisi emosi seseorang.

\section{Aspek-Aspek Kepuasan Konsumen}

Menurut Hutasoit (2011:24), ada beberapa metode untuk mengevaluasi kepuasan, meliputi:

1. Kinerja (Performance), Karakteristik pokok dari suatu produk dan merupakan karakteristik utama yang dipertimbangkan konsumen dalam membeli suatu produk

2. Ciri-ciri atau keistimewaan tambahan (Features), Dari fungsi dasar berkaitan dengan pilihanpilihan produk dan pengembangannya, yaitu karakteristik sekunder atau pelengkap 
3. Keandalan (Reability), Kecilnya kemungkinan suatu barang atau jasa rusak atau gagal fungsi dalam periode waktu tertentu dan kondisi tertentu.

4. Kesesuaian dengan spesifikasi (conformance to specification), Sejauh mana karakteristik desain dan operasi memenuhi standar yang ditetapkan sebelumnya berdasarkan keinginan konsumen.

5. Daya tahan (durability), Berkaitan dengan umur teknis dan umur produk.

6. Mudah diperbaiki (serviceability), Meliputi kecepatan, kompetensi, kenyamanan, mudah direparasi, serta penanganan keluhan yang memuaskan

7. Estetika (aesthetics), Daya tarik produk menurut pengindraan konsumen, misalnya model desain dan warna.

Kesimpulan dari teori diatas adalah persepsi kepuasan memiliki 7 aspek dalam memenuhi standar yang ditetapkan untuk menganalisis keluhan konsumen. Aspek-aspek ini sebagai alat ukur kepuasan dalam pelayanan kepada konsumen.

\section{Persepsi Kelayakan}

Menurut Muhammad Yusuf (2011:14), Jika seseorang memutuskan untuk membangun usaha atau bisnis baru, maha hal itu merupakan hasil process-oriented cognitive. Sebab ia mampu berpikir tentang hasil tersebut memang layak ata pantas diraihnya. Sebaliknya, ia tidak akan memutuskan untuk memulai suatu bisnis baru seandainya ia tidak menentukan hasil yang dicapai dan apakah hasil tersebut memang diinginkan dan layak untuk diperoleh. Teori harapan berusaha menjelaskan bagaimana sesungguhnya seseorang memilih hasil yang paling sesuai dengan keinginan atau harapannya. Teori ini menkonseptualisasikan motivasi sebagai hasil dari harapan (experiency), instrumentalitas (instrumentality) dan kapasitas untuk mengkombinasikannya (valence). Harapan adalah analog dengan persepsi kelayakan (Feasibility) dan Efikasi Diri yang biasa digunakan sebagai ukuran atau indikator untuk memprediksi motivasi wirausaha.

Kesimpulan diatas mengatakan bahwa persepsi kelayakan merupakan suatu alat ukur untuk memprediksi baik atau buruknya suatu jasa atau barang dalam perusahaan tersebut.

\section{Koperasi}

Menurut Supriyanto (2015:2), Koperasi adalah perkumpulan otonom dari orang-orang yang bersatu secara sukarela untuk memenuhi kebutuhan-kebutuhan dan aspirasi ekonomi, sosial dan budaya bersama-sama melalui perusahaan koperasi yang dimiliki bersama dan dikendalikan secara demokratis. Definisi tersebut menunjukan bahwa koperasi merupakan perkumpulan otonom dari orangorang secara sukarela yang mengakui, bahwa anggota yang mempunyai corak ragam yang berbeda dan pada definisi tersebut menekankan ada 4 poin menurut Ibnoe dalam Supriyanto (2015:2), yaitu:

1. Koperasi otonom

Berdiri sendiri, sejauh mungkin dari pemerintah dan perusahaan swasta.

2. Koperasi adalah perkumpulan orang

Berarti bahwa koperasi memiliki kebebasan untuk mendefinisikan orang-orang sesuai dengan ketentuan hukum yang dipilihnya.

3. Orang-orang bersatu secara sukarela

Keanggotaan tidak boleh merupakan keharusan, anggota harus bebas dalam batas tujuantujuan dan sumber daya koperasi, untuk bergabung atau menanggulangi.

4. Anggota memiliki kebutuhan yang sama

Berarti bahwa koperasi diorganisir oleh anggota-anggota untuk kemanfaatan bagi diri sendiri dan mereka bersama

Menurut Rudianto (2010:3) secara umum koperasi diartikan sebagai perkumpulan orang yang secara sukarela mempersatukan diri untuk berjuang meningkatkan kesejahteraan ekonomi mereka melalui pembentukan sebuah badan usaha yang dikelola secara demokratis. Menurut pasal $1 \mathrm{UU}$ No.25/1992 yang dimaksud dengan koperasi di Indonesia adalah badan usaha yang beranggotakan orang-orang atau badan hukum koperasi dengan melandaskan kegiatannya pada prinsip koperasi sekaligus sebagai gerakan ekonomi rakyat yang berdasarkan asas kekeluargaan.

Kesimpulan dari kutipan tersebut adalah bahwa koperasi merupakan sarana untuk membantu meningkatkan kesehjahteraan ekonomi banyak orang yang dibentuk oleh badan usaha maupun pemerintah yang dikelola secara hukum dan demokratis.

\section{Koperasi Simpan Pinjam}


Menurut El Shaddai (2015:37), koperasi simpan pinjam adalah koperasi yang usaha pokoknya adalah menggiatkan penabungan dan memberikan pinjam kepada anggotanya dengan bunga ringan, koperasi ini bertujuan untuk meningkatkan kesejahteraan anggotanya.

Menurut Rudianto dalam Angga dan Santika (2015:36), koperasi simpan pinjam adalah koperasi yang bergerak dalam bidang pemupukan simpanan dana dari para anggotanya, untuk kemudian dipinjamkan kembali kepada para anggota yang memerlukan bantuan dana. Sedangkan menurut Ninik Widiyanti dan Sunindhia (2009:198) simpan pinjam adalah: " Koperasi simpan pinjam adalah koperasi yang bergerak dalam lapangan usaha pembentukan modal melalui tabungan-tabungan para anggota secara teratur dan terus-menerus untuk kemudian dipinjamkan kepada para anggota dengan cara mudah, murah, cepat dan tepat untuk tujuan produktif dan kesejahteraan".

Sedangkan pengertian koperasi simpan pinjam menurut Suyanto dan Nurhadi (2003:43) adalah: "Koperasi simpan pinjam adalah merupakan koperasi yang meningkatkan kesejahteraan anggotanya dengan kegiatan kredit berbunga rendah."

Dapat disimpulkan bahwa kegunaan koperasi simpan pinjam untuk tujuan produktif dan kesehjateraan masyarakat umum. Keuntungan bagi pengguna ialah sebagai modal awal untuk usaha maupun keperluan pribadinya

\section{Metodologi Penelitian Tahapan Penelitian}

Dalam tahapan penelitian ini penulis melakukan tahapan penelitian deskriptif yang bertujuan untuk membuat secara sistematis, faktual dan akurat terhadap fakta-fakta dan sifat- sifat dari populasi daerah tertentu. Hal awal yang dilakukan pada penelitian ini adalah mengidentifikasi suatu kasus atau masalah yang terjadi pada perusahaan tersebut dan merumuskannya. Setelah itu melihat hipotesis peneliti ambil dan merumuskan persamaan yang berkaitan dengan penerimaan sistem di dalam Kostrad. Setelah itu di lakukan pengumpulan data dengan menyebar kuesioner kepada orang yang mempunyai hubungan dengan sistem yang berada pada Koperasi tersebut dan lakukan analisis dari pengumpulan data tersebut dan tentukan hasilnya.

\section{Instrumen Penelitian \\ Variabel Operasional}

Variabel menurut Sugiyono (2014:38) adalah suatu atribut atau sifat atau nilai dari orang, obyek atau kegiatan yang mempunyai variasi tertentu yang ditetapkan oleh peneliti untuk dipelajari dan kemudian ditarik kesimpulannya.

Pengertian variabel operasional menurut sugiyono (2010:58) adalah segala sesuatu yang berbentuk apa saja yang ditetapkan oleh peneliti untuk dipelajari sehingga diperoleh informasi tentang hal tersebut, kemudian ditarik kesimpulannya.

Variabel operasional merupakan suatu cara menetapkan kegiatan atau tindakan yang perlu dilakukan untuk mengukur variabel-variabel dalam penelitian. Berikut adalah variabel-variabel dalam penelitian:

1. Independent Variable (Variabel Bebas)

Variabel bebas adalah variabel yang tidak bergantung pada variabel lain dan digunakan untuk mengukur nilai variabel tidak bebas dependent variable). Variabel bebas penelitian ini adalah sebagaipersepsi kegunaan, kemudahan dan persepsi lifestyle. Dalam penelitian ini yang menjadi variabel bebas yaitu persepsi kepuasan pengguna terhadap penerimaan Sistem Koperasi Simpan Pinjam $\left(X_{1}\right)$, persepsi Kelayakan sistem terhadap penerimaan pengguna Sistem Koperasi Simpan $\left(\mathrm{X}_{2}\right)$.

2. Dependent Variable (Variabel Terikat)

Variabel terikat merupakan variabel yang bersifat tidak bebas yang bergantung pada variabel lainnya. Variabel yang dipengaruhi atau yang menjadi akibat, karena adanya variabel bebas. Variabel terikat penelitian ini adalah minat penggunaan. Dalam penelitian ini yang menjadi variabel terikat yaitu sikap dalam menggunakan Sistem Koperasi Simpan Pinjam (Y).

Pengukuran suatu variabel dilakukan dengan pengurangan dari tingkat abstaksi yaitu dengan operasionalisasi. Karena dengan operasionalisasi yang benar dapat diperkirakan akan menghasilkan item-item kuesioner yang mempunyai reliabilitas dan validitas yang diperlukan pada peneliti. Operasional Variabel independen dan dependen dalam penelitian terdapat dalam

Tabel 1 Pengukuran variabel dari X1, X2 dan Y 


\begin{tabular}{|c|c|c|c|}
\hline Variabel & Indikator & Item & Kode \\
\hline \multicolumn{4}{|c|}{ Variabel bebas (variabel independen)/ (X1) } \\
\hline $\begin{array}{lr}\text { Persepsi } & \text { kepuasan } \\
\text { pengguna } & \text { (Perceived } \\
\text { Usefulness) adalah sebuah } \\
\text { tingkatan dimana seorang } \\
\text { pengguna } \\
\text { merasakan manfaat dari } \\
\text { pelayanan menggunakan } \\
\text { sistem atau teknologi } \\
\text { tersebut akan } \\
\text { meningkatkan kualitas, } \\
\text { kuantitas dan kinerjanya. } \\
\text { Menurut Brenda dalam } \\
\text { Widyaharsana (2017:46). }\end{array}$ & $\begin{array}{ll}\text { - } & \text { Bermanfaat } \\
\text { terhadap pengguna } \\
\text { Kepuasaan dalam } \\
\text { penerimaan } \\
\text { pengguna } \\
\text { Meningkatkan } \\
\text { Kinerja } \\
\text { - } \text { Pekerjaan Menjadi } \\
\text { Lebih Efisien dan } \\
\text { Mudah } \\
\text { Pelayanan Koperasi } \\
\text { yang menjadi lebih } \\
\text { efektif }\end{array}$ & $\begin{array}{l}\text { - Kepuasan pengguna } \\
\text { terhadap pelayanan } \\
\text { buku tabungan dan } \\
\text { Peminjaman. } \\
\text { - Pekerjaan dalam } \\
\text { melayani anggota } \\
\text { menjadi mudah dan } \\
\text { cepat. }\end{array}$ & $\begin{array}{l}\text { A1 } \\
\text { A2 } \\
\text { A3 } \\
\text { A4 }\end{array}$ \\
\hline \multicolumn{4}{|c|}{ Variabel bebas (variabel independen)/ (X2) } \\
\hline $\begin{array}{l}\text { Persepsi Kelayakan untuk } \\
\text { pengguna (Perceived Ease } \\
\text { of Use) diartikan sebagai } \\
\text { persepsi r terhadap } \\
\text { kelayakan sistem bagi } \\
\text { pengguna Koperasi Simpan } \\
\text { Pinjam. }\end{array}$ & $\begin{array}{ll}\text { - } & \text { Kelayakan dalam } \\
& \text { pelayanan } \\
\text { - } & \text { Fleksibilitas } \\
& \text { Pengguna } \\
\text { - } & \text { Mudah untuk } \\
\text { dipahami dan } \\
\text { dipelajari } \\
\text { - } \\
\text { Kelayakan } \\
\text { dioperasikan }\end{array}$ & 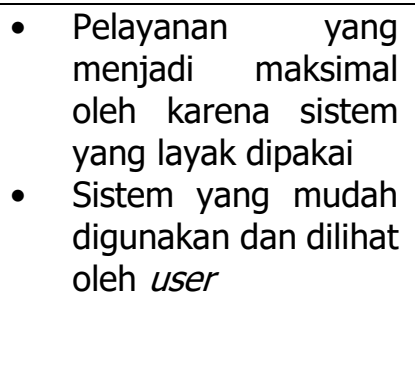 & $\begin{array}{l}\text { B1 } \\
\text { B2 } \\
\text { B3 } \\
\text { B4 }\end{array}$ \\
\hline \multicolumn{4}{|c|}{ Variabel terikat (variabel dependen)/ (Y) } \\
\hline $\begin{array}{lr}\text { Persepsi } & \text { Anggota } \\
\text { terhadap } & \text { perbaikan } \\
\text { layanan dari } & \text { Dampak } \\
\text { Penggunaan } & \text { Sistem } \\
\text { Koperasi Simpan } & \text { Pinjam } \\
\text { Divif 1 Kostrad Depok. }\end{array}$ & $\begin{array}{l}\text { Tidak menunggu } \\
\text { lama saat mengantri } \\
\text { - Tidak ada kesalahan } \\
\text { data saat peng- } \\
\text { inputan } \\
\text { - } \quad \text { Minim dari komplain }\end{array}$ & 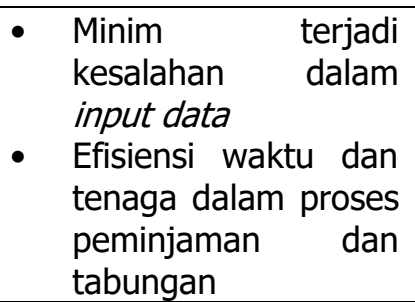 & $\begin{array}{l}\text { C1 } \\
\text { C2 } \\
\text { C3 } \\
\text { C4 }\end{array}$ \\
\hline
\end{tabular}

Dalam penelitian pengukuran bobot sikap dan persepsi seseorang yang digunakan adalah skala Likert untuk ruang lingkup seseorang atau sekumpulan orang atau gejala sosial. Dari setiap jawaban instrumen yang menggunakan skala Likert akan memberikan hasil gradasi dari sangat positif hingga sampai sangat negatif.Metode Pengumpulan Data, Populasi dan Sampel

\section{Metode Pengumpulan Data}

Penelitian ini menggunakan data primer yaitu data yang digabungkan dan diolah sendiri oleh peneliti langsung dari kumpulan responden berupa data opini dan data kuesioner yang disebarkan. Kuesioner berisi daftar pertanyaan yang terstruktur dan materinya berhubungan mengenai persepsi kelayakan,kepuasaan dan penerimaan sistem terhadap anggota Tentara Nasional Indonesia (TNI) Divif 1 Kostrad.

Teknik pengumpulan data dapat dilakukan dengan angket (kuesioner) dan kepustakaan.

1. Angket Kuesioner 
Penelitian ini merupakan sebuah teknik pengumpulan data angket atau kuesioner. Pengumpulan data ini dengan menyerahkan atau mengirimkan daftar pertanyaan untuk diisi oleh responden, dimana responden memberikan jawaban singkat memilih salah satu alternatif jawaban dari setiap pertanyaan yang telah tersedia sehingga hasilnya yang akan di analisis dan disimpulkan.

2. Studi Kepustakaan

Dalam penelitian sangat dibutuhkan studi kepustakaan digunakan dalam rangka untuk mendapatkan hasil dari data sekunder melalui usaha pengumpulan informasi yang berhubungan dengan materi teori-teori yang erat kaitannya dengan masalah dan variabel yang diteliti terhadap penggunaan Sistem Koperasi Simpan Pinjam dengan Technology Acceptance Model. Studi literatur tersebut didapat dari berbagai sumber yaitu: E-Journal library, skripsi, jurnal sistem informasi, serta media elektronik internet, dsb.

\section{Populasi dan Sampel}

Penelitian penulis menggunakan metode pengambilan sampel adalah menggunakan Sampling Purposive yaitu teknik pengumpulan sampel dengan pertimbangan tertentu (Sugiyono dalam Brenda 2017:49).

Dalam penetapan ukuran sampel menggunakan teknik Slovin dalam pengukuran.

Dimana :

$$
n=\frac{N}{1+\left(N e^{2}\right)}
$$

$\mathrm{n}=$ Ukuran Sampel

$\mathrm{N}=$ Populasi

$\mathrm{e}=$ Persentase kesalahan yang ditolerir dalam pengambilan sampel, pada kasus ini menggunakan

$10 \%(0,1)$

$n=\frac{830}{1+830(0,1)^{2}}$

$n=\frac{830}{9,3}$

$n=89$

Sampel ini ada dalam penelitian penerimaan pengguna sistem Koperasi Simpan Pinjam Koperasi Divif 1 Kostrad. Jumlah ukuran sampel sebanyak 89 responden dibagi menjadi 3 bagian yaitu Denpal, Denma dan Ajen yang merupakan posisi anggota TNI Kostrad. Menurut Roscoe dalam Sugiyono (2014:129) menyatakan bahwa ukuran sampel yang layak dalam penelitian adalah antara 30 sampai dengan 500.

\section{Analisis Deskriptif}

Dalam penelitian pernyataan untuk variabel ini memiliki 5 (lima) kriteria jawaban dengan cara diberikan skor dimulai dari 1, 2, 3, 4, dan 5. Dari setiap tanggapan responden tersebut akan dikategorikan menjadi 5 (lima) tingkatan penilaian yang terdiri dari "sangat tidak puas", "tidak puas", "cukup puas", "puas", dan "sangat puas" dengan perhitungan dasar menurut Sugiyono dalam Brenda (2017:67) sebagai berikut:

$$
\begin{aligned}
& \text { Range }=\text { Data terbesar }- \text { Data terkecil } \\
& \text { Interval Anggota TNI }=\frac{\text { Range }}{\text { Jumlah Anggota TNI }}
\end{aligned}
$$

Tetapi, Jika perhitungan ini diaplikasikasikan pada penelitian ini, maka penjumlahan statistik deskriptif tersebut dapat di simpulkan sebagai berikut:

$$
\text { Interval Kategori Skor }=\frac{\text { SIT }- \text { SIR }}{\text { Jumlah Kategori }}
$$

Keterangan:

SIT (skor ideal dari item tertinggi) = skor tertinggi $\mathrm{x}$ jumlah sampel $\mathrm{x}$ jumlah pernyataan 
SIR ( skor ideal dari item terendah $)=$ skor terendah $\mathrm{x}$ jumlah sampel $\mathrm{x}$ pernyataan

\section{Uji Validitas}

Uji validitas digunakan untuk mengukur sah atau valid tidaknya suatu kuesioner. Suatu kuesioner dikatakan valid jika pertanyaan pada kuesioner mampu untuk mengungkapkan sesuatu yang akan diukur oleh kuesioner tersebut.

\section{Analisis Koefisien Korelasi}

Kegunaan dari Analisis korelasi ialah untuk mencari arah dan kekuatan hubungan antara dua variabel atau lebih dari hipotesis peneliti. Dalam penghitungan nilai korelasi antara data pada masingmasing kuesioner dengan total skor menggunakan rumus teknik korelasi program SPSS (Statistical Product and Services Solution), sebagai berikut:

Keterangan :

$$
r=\frac{\mathrm{n}\left(\sum \mathrm{XY}\right)-\left(\sum \mathrm{X} \cdot \sum \mathrm{Y}\right)}{\left.\left.\sqrt{[n} \sum \mathrm{X}^{2}-\left(\sum X\right)^{2}\right] \sqrt{n} \cdot \sum Y^{2}-\left(\sum Y\right)^{2}\right]}
$$

$$
\begin{array}{ll}
\mathrm{R} & \text { : nilai korelasi } \\
\mathrm{N} & \text { : banyaknya subjek responden } \\
\mathrm{X} & \text { : skor setiap item } \\
\mathrm{Y} & \text { : skor total } \\
\mathrm{XY} & : \text { skor setiap item } \mathrm{x} \text { skor total } \\
\Sigma \mathrm{Y}^{2} & : \text { jumlah kuadrat skor total } \\
\Sigma \mathrm{X}^{2} & : \text { jumlah kuadrat skor item } \\
(\Sigma \mathrm{Y})^{2} & \text { : kuadrat jumlah skor total } \\
(\Sigma \mathrm{X})^{2} & \text { : kuadrat jumlah skor item }
\end{array}
$$

Tabel 3.3 Interprestasi Nilai $r$

\begin{tabular}{|c|l|}
\hline $\begin{array}{c}\text { (Sumber : Sugiyono dalam Brenda (2017:69)) } \\
\text { Interval } \\
\text { Koefisien }\end{array}$ & $\begin{array}{c}\text { Tingkat } \\
\text { Relasi/Hubungan }\end{array}$ \\
\hline $0,00-0,199$ & Sangat Rendah \\
\hline $0,20-0,399$ & Rendah \\
\hline $0,40-0,5999$ & Sedang \\
\hline $0,60-0,799$ & Kuat \\
\hline $0,80-1,000$ & Sangat Kuat \\
\hline
\end{tabular}

\section{Analisis Data}

\section{Hasil Analisis Penelitian}

Hasil Analisis Penelitian merupakan dari rumusan masalah yang terjadi, hasil penelitian hipotesis dan pengumpulan data kuesioner berdasarkan hasil melalui metode-metode dan analisis data pada saat peneliitan objek untuk tujuan mencari permasalahan terjadi diteliti sampai mendapatkan sebuah kesimpulan dan pengambilan keputusan yang bersifat fakta dan dapat dibuktikan kebenerannya.

\section{Responden Penelitian Perusahaan}


Dalam Penelitian ini penulis melakukan penyebaran kuesioner kepada Anggota Tentara Nasional Indonesia (TNI) Kostrad, Depok. Jumlah anggota Tentara di Kostrad Depok terdapat 830 orang responden dalam pembagian menjadi 89 responden dalam 3 satuan yaitu Denpal 35 orang responden, Denma 40 orang responden, Ajen 14 orang responden. Dalam Kuesioner tersebut berisi pertanyaan-pertanyaan mengenai persepsi kepuasan, persepsi kelayakan dan penerimaan pengguna terhadap sistem koperasi simpan pinjam yang berjumlah 12 pertanyaan.

Pembagian kuesioner tersebut dengan tujuan untuk menganalisis tingkat kepuasan, tingkat kelayakan dan penerimaan pengguna KSP Kostrad. Kuesioner yang telah diisi oleh responden kemudian dihitung dengan Ms. Excel dan Aplikasi SPSS untuk di olah data sampai didapat hasil seperti yang akan dijelaskan di bawah ini.

\section{Responden Berdasarkan Jenis Kelamin}

Pengambilan sampel melalui gambaran umum mengenai profil responden yang diklasifikasikan berdasarkan jenis kelamin. Hasil pengumpulan data dapat dirinci pada tabel berikut ini :

Tabel 4.1 Responden Berdasarkan Jenis Kelamin

\begin{tabular}{|c|l|l|l|}
\hline No & Jenis kelamin & Jumlah & Persentase (\%) \\
\hline 1. & Laki-laki & 74 & $83.15 \%$ \\
\hline 2. & Perempuan & 15 & $16.85 \%$ \\
\hline \multicolumn{2}{r|}{ Total } & 89 & $100 \%$ \\
\hline
\end{tabular}

Berdasarkan tabel 4.1 di atas bahwa responden pengguna sistem KSP Kostrad didominasi oleh responden laki-laki yaitu berjumlah 74 orang. Sedangkan responden perempuan yaitu berjumlah 15 orang. Jumlah responden didominasi oleh laki-laki dikarenakan anggota TNI Kostrad Depok dikhususkan populasi lebih banyak laki-laki untuk tujuan keamanan.

\section{Responden Berdasarkan Pangkat}

Pengambilan sampel melalui gambaran umum mengenai profil responden yang diklasifikasikan berdasarkan pangkat TNI Kostrad. Hasil pengumpulan data dapat dirinci sebagai tabel berikut ini :

Tabel 4.2 Responden Berdasarkan Pangkat

\begin{tabular}{|c|l|c|}
\hline No & \multicolumn{1}{|c|}{ Pangkat } & Frekuensi \\
\hline 1. & Prada (Prajurit 2) & 4 \\
\hline 2. & Pratu (Prajurit 1) & 5 \\
\hline 3. & Praka (Prajurit Kepala) & 6 \\
\hline 4. & Kopda (Kopral 2) & 5 \\
\hline 5. & Koptu (Kopral 1) & 7 \\
\hline 6. & Kopka (Kopral Kepala) & 9 \\
\hline 7. & Serda (Sersan 2) & 5 \\
\hline 8. & Sertu (Sersan 1) & 7 \\
\hline
\end{tabular}




\begin{tabular}{|c|l|c|}
\hline 9. & Serka (Sersan Kepala) & 10 \\
\hline 10. & Serma (Sersan Mayor) & 8 \\
\hline 11. & Pelda (Pembantu letnan 2) & 5 \\
\hline 12. & Peltu (Pembantu letnan 1) & 4 \\
\hline 13. & Letda (Letnan 2) & 5 \\
\hline 14. & Lettu (Letnan 1) & 4 \\
\hline 15. & Kapten Inf & 2 \\
\hline 16. & Mayor Inf & 2 \\
\hline 17. & Kolonel Inf & 1 \\
\hline & Total & $\mathbf{8 9}$ \\
\hline
\end{tabular}

Dari tabel 4.2 di atas dapat diketahui bahwa responden pengguna sistem KSP Kostrad lebih banyak oleh responden berpangkat Sersan Kepala (Serka) karena populasi terbaru saat ini rata-rata Tentara Kostrad mengambil kepangkatan melalui jalur Bintara yang merupakan pangkat Sersan. Dan responden yang mempunyai pangkat sedikit ialah Kolonel Infanteri yang merupakan jalur Perwira.

Dikarenakan dia merupakan seorang pimpinan dalam sebuah divisi di Kostrad selain Panglima Kostrad memimpin semua divisi.

\section{Responden Berdasarkan Satuan}

Pengambilan sampel melalui gambaran umum profil responden yang diklasifikasikan berdasarkan satuan divisi TNI Kostrad. Hasil pengumpulan data dapat dirinci pada tabel sebagai berikut :

Tabel 4.3 Responden Berdasarkan Satuan

\begin{tabular}{|c|l|c|c|}
\hline No & Satuan & Jumlah & Persentase (\%) \\
\hline 1. & Denpal & 35 & $39.33 \%$ \\
\hline 2. & Denma & 40 & $44.94 \%$ \\
\hline 3. & Ajen & 14 & $15.73 \%$ \\
\hline \multicolumn{2}{r|}{ Total } & 89 & $100 \%$ \\
\hline
\end{tabular}

Berdasarkan tabel 4.3 di atas bahwa responden pengguna sistem KSP Kostrad didominasi oleh responden satuan Denma yaitu berjumlah 40 orang. Sedangkan responden yang paling sedikit ialah satuan Ajen yaitu 14 orang. Dikarenakan populasi Ajen yang sangat jarang berada di Kostrad Depok oleh karena penempatan tugas masing-masing. 
Penjumlahan dari hasil variabel - variabel kuesioner dengan responden dengan menggunakan tingkat interval.

$$
\text { Rumus }=\frac{\text { skor total tertinggi-skor total terendah }}{\text { kategori skala (lima) }}
$$

Hasil Skor tertinggi (SIT) :

$=$ skor total tertinggi $\mathrm{x}$ jumlah responden $\mathrm{x}$ jumlah nomor pertanyaan

$=5 \times 89 \times 4=1780$

Hasil Skor terendah (SIR)

$=$ skor total terendah $\mathrm{x}$ jumlah responden $\mathrm{x}$ jumlah nomor pertanyaan

$=1 \times 89 \times 4=356$

Range $=$ SIT - SIR $=1780-356=1424$

Interval $=$ Range $=1780-356=285$

$$
5 \quad 5
$$

1. $356+285=641$

2. $641+285=926$

3. $926+285=1211$

4. $1211+285=1496$

5. $1496+285=1781$

Tingkat interval:

1. $356-641=$ Sangat Tidak Setuju

2. $641-926=$ Tidak Setuju

3. $926-1211=$ Cukup Setuju

4. $1211-1496$ = Setuju

5. $1496-1781$ = Sangat Setuju

Dari hasil pengolahan data statistik tiap variabel atau butir pernyataan dari tanggapan responden, sesuai dengan indikator-indikator yang telah ditentukan peneliti dalam kuesioner, variabel persepsi

\begin{tabular}{|c|c|c|c|c|c|c|c|c|}
\hline \multirow[b]{2}{*}{ No. } & \multirow[b]{2}{*}{ Pernyataan } & \multicolumn{5}{|c|}{ Skor } & \multirow[b]{2}{*}{$\begin{array}{l}\text { Skor } \\
\text { Total }\end{array}$} & \multirow[b]{2}{*}{$\%$} \\
\hline & & $\begin{array}{l}\text { STS } \\
\text { (1) }\end{array}$ & $\begin{array}{l}\text { TS } \\
\text { (2) }\end{array}$ & $\begin{array}{l}\text { CS } \\
\text { (3) }\end{array}$ & $\begin{array}{c}S \\
(4)\end{array}$ & $\begin{array}{l}\text { SS } \\
\text { (5) }\end{array}$ & & \\
\hline 1. & $\begin{array}{l}\text { Sistem Koperasi Simpan } \\
\text { Pinjam bermanfaat dalam } \\
\text { ruang lingkup peminjaman } \\
\text { dan tabungan anggota } \\
\text { koperasi. }\end{array}$ & 2 & 13 & 28 & 32 & 14 & 310 & $70 \%$ \\
\hline 2. & $\begin{array}{l}\text { Penggunaan Sistem KSP dapat } \\
\text { meningkatkan kinerja } \\
\text { karyawan dalam melayani } \\
\text { anggota koperasi. }\end{array}$ & $\mathbf{0}$ & 9 & 29 & 40 & 11 & 320 & $72 \%$ \\
\hline
\end{tabular}
kepuasan dapat diambil kesimpulan melalui statistik sebagai berikut :

Tabel 4.8 Akumulasi dari tanggapan responden dari variabel X1 


\begin{tabular}{|l|l|l|l|l|l|l|l|l|}
\hline 3. & $\begin{array}{l}\text { Menggunakan Sistem KSP } \\
\text { meningkatkan efisiensi dalam } \\
\text { pelayanan para } \\
\text { anggota koperasi. }\end{array}$ & $\mathbf{0}$ & $\mathbf{6}$ & $\mathbf{3 5}$ & $\mathbf{3 3}$ & $\mathbf{1 5}$ & $\mathbf{3 2 4}$ & $\mathbf{7 3 \%}$ \\
\hline 4. & $\begin{array}{l}\text { Sistem KSP membuat } \\
\text { pekerjaan menjadi lebih } \\
\text { mudah dalam peminjaman } \\
\text { dan tabungan. }\end{array}$ & $\mathbf{0}$ & $\mathbf{5}$ & $\mathbf{3 5}$ & $\mathbf{2 3}$ & $\mathbf{2 6}$ & $\mathbf{3 3 7}$ & $\mathbf{7 6 \%}$ \\
\hline
\end{tabular}

Hasil interval dapat di tentukan dengan mengelompokkan kedalam variabel persepsi kepuasan sebagai berikut :

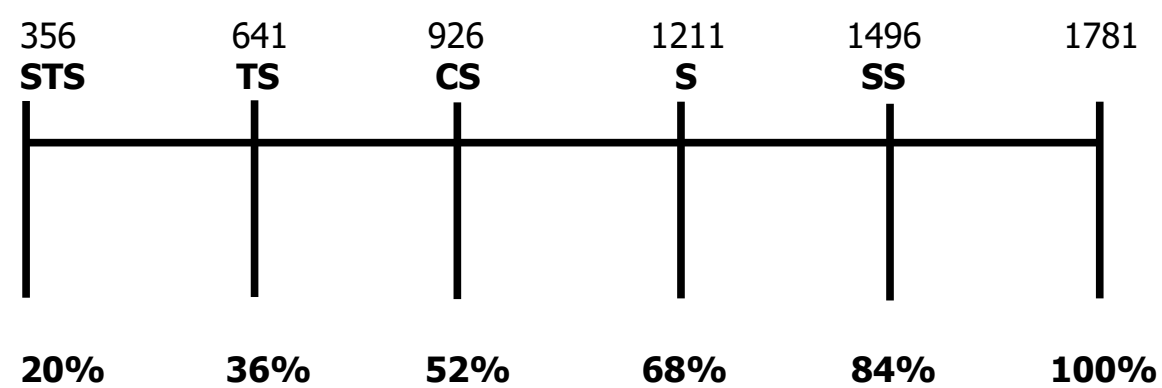

Melalui hasil pengolahan data kuesioner tersebut pada tabel 4.8, bahwa variabel persepsi kepuasan dari 4 pernyataan tersebut hasilnya sebesar 1291 berada diantara interval $1211-1496$. Dapat diartikan, bahwa responden dikategorikan setuju dalam menggunakan sistem koperasi simpan pinjam tersebut.

\section{Analisis Persepsi Kelayakan Sistem Koperasi Simpan Pinjam}

Dari hasil pengolahan data statistik tiap variabel atau butir pernyataan dari tanggapan responden, sesuai dengan indikator-indikator yang telah ditentukan peneliti dalam kuesioner, variabel persepsi kepuasan dapat diambil kesimpulan melalui statistik sebagai berikut:

Tabel 4.13 Akumulasi dari tanggapan responden dari variabel X2

\begin{tabular}{|c|c|c|c|c|c|c|c|c|}
\hline \multirow[b]{2}{*}{ No. } & \multirow[b]{2}{*}{ Pernyataan } & \multicolumn{5}{|c|}{ Skor } & \multirow[b]{2}{*}{$\begin{array}{l}\text { Skor } \\
\text { Total }\end{array}$} & \multirow[b]{2}{*}{$\%$} \\
\hline & & $\begin{array}{l}\text { STS } \\
(1)\end{array}$ & $\begin{array}{l}\text { TS } \\
(2)\end{array}$ & $\begin{array}{l}\text { CS } \\
\text { (3) }\end{array}$ & $\begin{array}{l}5 \\
(4)\end{array}$ & $\begin{array}{l}\text { SS } \\
(5)\end{array}$ & & \\
\hline 5. & $\begin{array}{l}\text { Sistem KSP Kostrad } \\
\text { sangat layak dan mudah } \\
\text { dipahami }\end{array}$ & $\mathbf{0}$ & 4 & 30 & 29 & 26 & 344 & $77.3 \%$ \\
\hline 6. & $\begin{array}{l}\text { Fleksibilitas anggota } \\
\text { koperasi dalam melakukan } \\
\text { kegiatan simpan pinjam. }\end{array}$ & 0 & 5 & 25 & 38 & 21 & 342 & $76.9 \%$ \\
\hline 7. & $\begin{array}{l}\text { Sistem KSP memudahkan } \\
\text { pelayanan kebutuhan } \\
\text { peminjaman dan tabungan. }\end{array}$ & $\mathbf{0}$ & 14 & 30 & 31 & 14 & 312 & $70.1 \%$ \\
\hline 8. & $\begin{array}{l}\text { Sistem KSP sangat mudah di } \\
\text { operasikan oleh anggota } \\
\text { koperasi }\end{array}$ & 1 & 13 & 25 & 28 & 22 & 323 & $72.6 \%$ \\
\hline & & & & & & & 1321 & $74.2 \%$ \\
\hline
\end{tabular}


Hasil interval dapat di tentukan dengan mengelompokkan kedalam variabel persepsi kepuasan sebagai berikut :

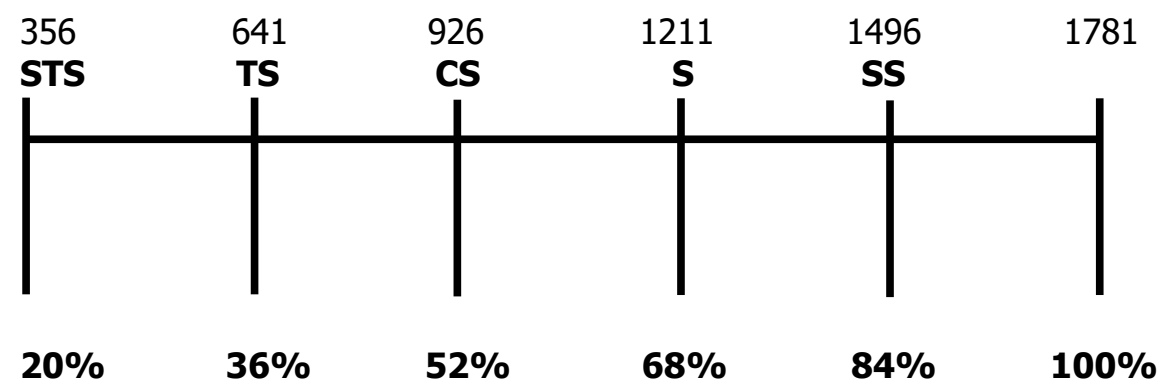

Melalui hasil pengolahan data kuesioner tersebut pada tabel 4.13, bahwa variabel persepsi kelayakan dari 4 pernyataan tersebut hasilnya sebesar 1321 berada diantara interval $1211-1496$. Dapat diartikan, bahwa responden dikategorikan setuju dalam menggunakan sistem koperasi simpan pinjam tersebut.

\section{Analisis Penerimaan Pengguna Terhadap Sistem KSP}

Dari hasil pengolahan data statistik tiap variabel atau butir pernyataan dari tanggapan responden, sesuai dengan indikator-indikator yang telah ditentukan peneliti dalam kuesioner, variabel persepsi kepuasan dapat diambil kesimpulan melalui statistik sebagai berikut :

Tabel 4.18 Akumulasi dari tanggapan responden dari variabel $Y$

\begin{tabular}{|c|c|c|c|c|c|c|c|c|}
\hline \multirow[b]{2}{*}{ No. } & \multirow[b]{2}{*}{ Pernyataan } & \multicolumn{5}{|c|}{ Skor } & \multirow[b]{2}{*}{$\begin{array}{l}\text { Skor } \\
\text { Total }\end{array}$} & \multirow[b]{2}{*}{$\%$} \\
\hline & & $\begin{array}{l}\text { STS } \\
\text { (1) }\end{array}$ & $\begin{array}{l}\text { TS } \\
(2)\end{array}$ & $\begin{array}{l}\text { CS } \\
(3)\end{array}$ & $\begin{array}{l}5 \\
(4)\end{array}$ & $\begin{array}{l}\text { SS } \\
(5)\end{array}$ & & \\
\hline 9. & $\begin{array}{l}\text { Saya merasa puas dalam } \\
\text { menggunakan Sistem KSP }\end{array}$ & 3 & 13 & 26 & 38 & 9 & 304 & $68.3 \%$ \\
\hline 10. & $\begin{array}{l}\text { Saya senang dalam } \\
\text { menggunakan aplikasi } \\
\text { sistem KSP ini }\end{array}$ & 5 & 8 & 23 & 41 & 12 & 314 & $70.6 \%$ \\
\hline 11. & $\begin{array}{l}\text { Saya merasa nyaman } \\
\text { dalam pelayanan Sistem } \\
\text { KSP. }\end{array}$ & 1 & 10 & 27 & 38 & 13 & 319 & $71.7 \%$ \\
\hline 12. & $\begin{array}{l}\text { Saya mendapat informasi } \\
\text { yang jelas dari data koperasi } \\
\text { yang berhubungan dengan } \\
\text { peminjaman dan tabungan } \\
\text { anggota koperasi }\end{array}$ & 2 & 11 & 29 & 32 & 15 & 314 & $70.6 \%$ \\
\hline & & & & & & & 1251 & $70.3 \%$ \\
\hline
\end{tabular}


Hasil interval dapat di tentukan dengan mengelompokkan kedalam variabel persepsi kepuasan sebagai berikut:

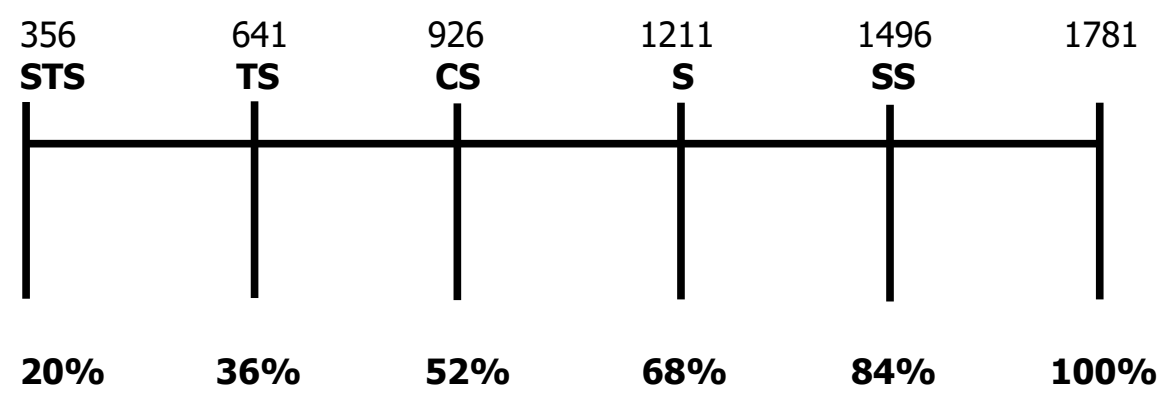

Melalui hasil pengolahan data kuesioner tersebut pada tabel 4.18, bahwa variabel persepsi kelayakan dari 4 pernyataan tersebut hasilnya sebesar 1251 berada diantara interval $1211-1496$. Dapat diartikan, bahwa responden dikategorikan setuju dalam menggunakan sistem koperasi simpan pinjam tersebut.

\section{Uji Validitas dan Realibilitas}

Uji validitas digunakan untuk memberikan hasil dari setiap item variabel pernyataan kuesioner tersebut valid atau tidak. Penelitian ini melakukan uji validitas dengan menggunakan rumus corre/pada microsoft exce/dan korelasi bivariate pearson dengan menggunakan program SPSS. Item ini dapat dikatakan valid jika nilai $r$ hitung $>r$ tabel pada nilai signifikansi $5 \%$. Begitu sebaliknya jika nilai $r$ hitung $<r$ tabel pada nilai signifikansi $5 \%$ itu tidak valid. Adapun hasil uji validitas berbentuk tabel dan SPSS sebagai berikut:

Tabel 4.19 Hasil Uji Validitas Variabel X1 Menggunakan Ms.Excel

\begin{tabular}{|c|c|c|c|}
\hline No Item & $\mathbf{r}$ Hitung & $\mathbf{r}$ tabel 5\% (30) & Keterangan \\
\hline 1 & 0,760 & 0,361 & Valid \\
\hline 2 & 0,701 & 0,361 & Valid \\
\hline 3 & 0,706 & 0,361 & Valid \\
\hline 4 & 0,801 & 0,361 & Valid \\
\hline
\end{tabular}

Tabel 4.20 Hasil Uji Validitas Variabel X2 Menggunakan Ms.Excel

\begin{tabular}{|c|c|c|c|}
\hline No Item & $\mathbf{r}$ Hitung & $\mathbf{r}$ tabel 5\% (30) & Keterangan \\
\hline 5 & 0,741 & 0,361 & Valid \\
\hline 6 & 0,750 & 0,361 & Valid \\
\hline 7 & 0,802 & 0,361 & Valid \\
\hline 8 & 0,733 & 0,361 & Valid \\
\hline
\end{tabular}

Tabel 4.21 Hasil Uji Validitas Variabel Y Menggunakan Ms. Excel

\begin{tabular}{|c|c|c|c|}
\hline No Item & $\mathbf{r}$ Hitung & $\mathbf{r}$ tabel 5\% (30) & Keterangan \\
\hline 9 & 0,771 & 0,361 & Valid \\
\hline 10 & 0,800 & 0,361 & Valid \\
\hline 11 & 0,834 & 0,361 & Valid \\
\hline 12 & 0,772 & 0,361 & Valid \\
\hline
\end{tabular}


Pengumpulan dari data-data diatas dapat disimpulkan bahwa teori cronbach's alpha sebesar 0,813 maka diketahui bahwa instrumen setiap penelitian tersebut reliabel dan konsisten sehingga penelitian dapat di gunakan berkali-kali dengan kriteria pada tabel keandalan cronbach's alpha dengan tingkat keandalan "Sangat Konsisten" sesuai dengan kriteria pada tabel ini :

\begin{tabular}{|c|c|}
\hline Nilai Cronbach's Alpha & Konsisten \\
\hline $0,0-0,20$ & Kurang Konsisten \\
\hline$>0,20-0,40$ & Agak Konsisten \\
\hline$>0,40-0,60$ & Cukup Konsisten \\
\hline$>0,60-0,80$ & Konsisten \\
\hline$>0,80-1.00$ & Sangat Konsisten \\
\hline
\end{tabular}

\section{Analisis Regresi Linier Berganda}

Hasil pengolahan tabel diatas diketahui persamaan regresi sebagai berikut:

$$
\begin{aligned}
& Y=a+b_{1} X_{1}+b_{2} X_{2} \\
& Y=5,463+1,633 X_{1}+0,793 X_{2}
\end{aligned}
$$

Keterangan :

$$
\begin{array}{ll}
\mathrm{Y} & =\text { Penerimaan Pengguna } \\
\mathrm{a} & =\text { Konstanta } \\
\mathrm{b}_{1}, \mathrm{~b}_{2} & =\text { Koefisien Regresi } \\
\mathrm{X}_{1} & =\text { Persepsi Kepuasan } \\
\mathrm{X}_{2} & =\text { Persepsi Kelayakan }
\end{array}
$$

Dari nilai persamaan angka diatas dapat diinterprestasikan sebagai berikut:

1. Hasil yang didapat bahwa konstanta bernilai sebesar 5,463 dengan koefisien persepsi kepuasan $\left(\mathrm{X}_{1}\right)$ dan persepsi kelayakan $\left(\mathrm{X}_{2}\right)$ bernilai nol $(0)$. Berarti tanpa menggunakan persepsi kepuasan dan persepsi kelayakan sistem koperasi simpan pinjam nilai dari penerimaan pengguna koperasi simpan pinjam tetap ada dan positif.

2. Hasil Koefisien regresi persepsi kepuasan $\left(X_{1}\right)$ sebesar 1,633 berarti peningkatan satuan persepsi kepuasan dengan asumsi variabel bebas akan terjadi peningkatan nilai penerimaan pengguna sebesar 1,633 . Nilai koefisien menjadi positif artinya terjadi hubungan positif dari persepsi kepuasan dengan penerimaan pengguna, sehingga semakin tinggi persepsi kepuasan semakin tinggi penerimaan pengguna terhadap koperasi simpan pinjam.

3. Hasil Koefisien regresi persepsi kelayakan $\left(X_{2}\right)$ sebesar 0,793 berarti peningkatan satuan persepsi kelayakan dengan asumsi variabel bebas akan terjadi peningkatan nilai penerimaan pengguna sebesar 0,793 . Nilai koefisien menjadi positif artinya terjadi hubungan positif dari persepsi kelayakan dengan penerimaan pengguna, sehingga semakin tinggi persepsi kelayakan semakin tinggi penerimaan pengguna terhadap koperasi simpan pinjam.

4. Dari hasil koefisien regresi pada variabel persepsi kepuasan $\left(X_{1}\right)$ dan variabel persepsi kelayakan $\left(\mathrm{X}_{2}\right)$ maka didapati bahwa nilai variabel yang paling dominan ialah variabel $\left(\mathrm{X}_{1}\right)$ daripada $\left(\mathrm{X}_{2}\right)$ dengan nilai 1,633. Maka dengan kata lain variabel kepuasan dapat dikatakan memiliki pengaruh terhadap variabel penerimaan pengguna terhadap koperasi simpan pinjam ( $\mathrm{Y}$ ).

\section{Hasil dan Pembahasan}

Pembahasan dari hasil penelitian ini dilakukan analisis data dan pengujian 3 hipotesis tersebut berdasarkan model teoritis yang di uji menggunakan program SPSS, yang merupakan hasil kesimpulan keseluruhan penelitian. Tahapan tersebut di bahas sebagai berikut :

1. Melakukan uji validitas dari setiap item variabel pernyataan yang sudah dikatakan valid. Berikut dengan hasil uji realibilitas diketahui bahwa bernilai 0,813 sehingga dapat dikatakan bahwa tingkat reliabel atau konsistennya "Sangat Konsisten" berdasarkan teori cronbach's alpha .

2. Pengujian regresi berganda dapat diperoleh hasil nilai koefisien yang sama-sama positif. 
Sehingga dapat disimpulkan bahwa setiap peningkatan variabel $X_{1}$ dengan $X_{2}$ akan ikut secara signifikan dengan peningkatan $\mathrm{Y}$.

3. Hasil koefisien korelasi $(R)$ menyatakan bahwa korelasinya positif. Sehingga dapat disimpulkan ada hubungan yang kuat dengan searah, dimana setiap perubahan-perubahan peningkatan variabel $X_{1}$ dengan $X_{2}$ akan diikuti dengan peningkatan variabel $Y$.

4. Hasil penelitian diperoleh bahwa variabel $X_{1}$ dengan $X_{2}$ yaitu persepsi kepuasan dengan persepsi kelayakan merupakan variabel bebas yang dominan sangat mempengaruhi Penerimaan Pengguna terhadap KSP.

5. Analisis pengaruh Persepsi Kepuasan dan Persepsi Kelayakan dengan Penerimaan Pengguna terhadap sistem KSP. Ditemukan bahwa ada pengaruh signifikan sehingga dari penelitian ini disimpulkan bahwa sangat berpengaruh antara variabel persepsi kepuasan dan persepsi kelayakan dengan Penerimaan pengguna terhadap sistem koperasi simpan pinjam berpengaruh terhadap pelayanan anggota koperasi simpan pinjam. Sehingga efektifnya pelayanan karyawan terhadap anggota akan bergantung dari sistem yang digunakan saat ini didalam Koperasi Divif 1 Kostrad.

\section{Kesimpulan dan Saran Kesimpulan}

Setelah melakukan penelitian dengan menghitung manfaat dari setiap variabel $\mathrm{X}$ dan $\mathrm{Y}$ dari penerimaan pengguna terhadap sistem koperasi simpan, maka ditarik kesimpulan terhadap masalah yang diidentifikasi adalah :

1. Penggunaan sistem Koperasi Simpan Pinjam dari hasil analisis dan penyebaran kuesioner sangat berpengaruh secara signifikan terhadap perbaikan layanan anggota.

2. Dari hasil uji hipotesis bahwa Persepsi Kepuasan dan Persepsi Kelayakan

\section{Saran} diantaranya :

Dalam penelitian ini dikemukakan saran yang akan bermanfaat bagi Kantor KSP Divif 1 Kostrad,

1. Peningkatan kualitas Sistem yang digunakan harus segera di implementasikan agar Koperasi dapat meyakinkan anggota akanmendapatkan pelayanan yang terbaik.

2. Menambah tempat penyimpanan (cloud system) terhadap data nasabah.

3. Perusahaan ini disarankan memberikan pelatihan khusus untuk menjangkau seluruh useryang belum paham tentang pelayanan sistem Koperasi Simpan Pinjam di Divif 1 Kostrad Depok.

\section{Referensi}

1. Anggadini, S. D. (n.d.). Analisis Sistem Informasi Manajemen Berbasis Komputer Dalam Proses Pengambilan Keputusan. Majalah IImiah UNIKOM, Vol.11 No.2.

2. Bayu, M (2016). Pengaruh Kompensasi, Lingkungan Kerja dan Promosi Jabatan Terhadap Kepuasan Kerja. E-Jurnal Managemen Unud, Vol.5, No.1. Bali

3. Claudya, B. (2017). Analisis Pengaruh Persepsi Manfaat Dan Persepsi Kemudahan Terhadap Sikap Pengguna Sistem Online UNAI Menggunakan Metode TAM. Universitas Advent Indonesia.

4. C.S.Hutasoit. (2011). Pelayanan Publik Teori dan Aplikasi, Jakarta: MagnaScript Publishing

5. Dalimunthe, Wibisono. (2013). Analisis Penerimaan Sistem E-Learning SMK Labor Pekanbaru dengan menggunakan metode Technology Acceptance Model (TAM), Jurnal Sains, Teknologi, dan Industri,11(1),3-4

6. Fatmasari, Ariandi.(2013). Penerimaan Metode Technology Acceptance Mode/(TAM) terhadap Penerimaan KRS Online, Jurnal IImiah Matrik, 16(2), 3-5

7. Hutahaean, Jeperson. (2014). Konsep Sistem Informasi. Edisi 1. Yogyakarta: Deepublish.

8. Junaidi, R. (2015). Analisis Perbandingan Sistem Informasi Pengiriman Barang Pada PT. Pos Indonesia Kantor Cimahi Dan PT. JNE. Universitas Advent Indonesia.

9. Kotler \& Keller, (2009), Managemen Pemasaran. Jilid I. Edisi Ke 13 Jakarta: Erlangga

10. Oktavianus, N. (2015). Analisis Dan Perancangan Sistem Informasi Koperasi Simpan Pinjam Pada KSP Kodanua. Journal Library Bina Nusantara.(2)-00442 
11. Pratama, A., \& Ferdani, S. F. (2015). Analisis Dan Perancangan Aplikasi Basis Data Simpan Berbasis Web Pada Koperasi Simpan Pinjam Kemauan Bersama. Journal Library Bina Nusantara.(1)-01211-IF

12. Riduwan. (2014). Menyusun dan Teknik Menyusun Tesis. Bandung: Alfabeta

13. Sitio, A., \& Tamba, H. (2001). Koperasi Teori dan Praktik. Jakarta: Erlangga.

14. Sujarweni, V. W. (2015). SPSS Untuk Penelitian. Yogyakarta: Pustaka Baru Press

15. Supriyanto, A. (2015). Tata Kelola Koperasi Kredit atau Koperasi Simpan Pinjam. Yogyakarta: Andi Offset.

16. Seputra, Y. E. (2013). Belajar dan Analisis Tuntas Statistika Berbasis Komputer Jakarta : Mitra Wacana Media

17. Sugiyono. (2013). Metode Penelitian Kuantitatif, Kualitatif, dan R\&D. Bandung: Alfabeta 